\title{
In regard to Minniti et al.: Current status and recent advances in resection cavity irradiation of brain metastases - roundup to cover all angles
}

\author{
Gustavo R. Sarria ${ }^{1}$ (D), Christopher P. Cifarelli ${ }^{2}$, Henning Kahl ${ }^{3}$ and Frank A. Giordano ${ }^{1^{*}}$
}

\begin{abstract}
We read with great interest the recent review, entitled "Current status and recent advances in resection cavity irradiation of brain metastases". It is a comprehensive summary of currently available techniques for treatment of post-resection cavity in patients with this diagnosis. We would like to complement this manuscript by including intraoperative techniques as other viable approaches in the management of these patients.
\end{abstract}

Keywords: Brain metastases, Intraoperative radiotherapy, Brachytherapy, Kilovoltage

\section{Letter body}

In regard of the recently published review by Minniti et al. [1], which summarizes the current evidence on resection cavity irradiation of brain metastases (BM), we would like to provide our insights of other methods for this purpose. The development of intraoperative radiotherapy (IORT) over the past four decades has opened a vast spectrum of possible applications for malignancy treatment. Since the first published experiences from Japan in the early 1980's on treating gliomas and BM, employing an electron-based IORT device (IOERT), timely resurgence of this technique has paved its road to evolving into a modern therapeutic alternative for BM. In addition, a growing body of evidence for intraoperative brachytherapy further contributes to widen the therapeutic arsenal in this setting.

This comment refers to the article available online at https://doi.org/10.1186/ s13014-021-01802-9.

*Correspondence: frank.giordano@ukbonn.de

${ }^{1}$ Department of Radiation Oncology, University Hospital Bonn, University of Bonn, Venusberg Campus 1 Building 55, 53127 Bonn, Germany

Full list of author information is available at the end of the article
Although no large randomized trials are available, both historical and current evidence in the management of BM with brachytherapy implants support this irradiation method. Reinforcing historical reports from over 25 years ago [2], a more recent prospective study demonstrated the feasibility and safety of applying $\mathrm{Cs}^{131}$ intraoperatively to the resection cavity in 42 patients carrying $46 \mathrm{BM}$, prescribing $80 \mathrm{~Gy}$ at $5 \mathrm{~mm}$ depth, reaching a local control rate of $100 \%$ after 1.5 years with no cases of radionecrosis (RN) [3]. Successive retrospective analysis have suggested similar results, with a relatively low rate of RN $[4,5]$. However, evidence from these rather small cohorts should be carefully interpreted.

The dawn of IORT is directly related to low-energy $\mathrm{x}$-rays (kilovoltage- $\mathrm{kV}$ ), initially published as early as 1907 for treatment of abdominal malignancies [6]. Modern technology has adapted $\mathrm{kV}$ units to portable and versatile devices. Their generally low shielding requirements turns them of use for in- and outpatient management. Under the general principle of highconformal dose distribution and healthy tissue sparing, this sharp fall-off dose of $50-\mathrm{kV}$ accelerators enables concentrating increased doses on a quite well defined original author(s) and the source, provide a link to the Creative Commons licence, and indicate if changes were made. The images or other third party material in this article are included in the article's Creative Commons licence, unless indicated otherwise in a credit line to the material. If material is not included in the article's Creative Commons licence and your intended use is not permitted by statutory regulation or exceeds the permitted use, you will need to obtain permission directly from the copyright holder. To view a copy of this licence, visit http://creativecommons.org/licenses/by/4.0/. The Creative Commons Public Domain Dedication waiver (http://creativeco mmons.org/publicdomain/zero/1.0/) applies to the data made available in this article, unless otherwise stated in a credit line to the data. 
target area. Treatment application through a spherical applicator allows a homogeneous delivery doses in a circumferential fashion, providing excellent coverage of the entire resection cavity and a steep dose drop to approximately $30 \%$ of the surface dose at $1 \mathrm{~cm}$ [7]. Nevertheless, it must be noted that thorough patient selection should be performed, in order to determine applicability, proximity to organs at risk (OAR) and dose to deliver. Furthermore, a final decision might be made only during resection, after live assessment under direct view.

An early IOERT report with a considerable number of patients with BM including 43 metastatic lesions treated with a mean 19.9 Gy (18-25) dose prescribed at $1-\mathrm{cm}$ depth, resulted in seven patients developing local failure within 1 year after treatment. Being approximately an $84 \%$ rate, these results remain comparable to those resection plus whole-brain radiotherapy (WBRT) or stereotactic radiosurgery (SRS) approaches [8]. Nonetheless, elevated rates of "encephalic atrophy" and "dementia" were described, likely due to the large healthy-tissue volume exposed to the prescription dose [9].

Dosimetric comparisons have determined the feasibility of dose escalation with kilovoltage-IORT $(\mathrm{kV}$ IORT), confirming a clear benefit in terms of healthy tissue sparing [10]. After these considerations, initial clinical experiences with kV-IORT have been reported during the last decade. A recent multi-institutional retrospective study by our group reported on 54 patients who received superficial doses of mostly 20-30 Gy, with 1-year local control and overall survival rates of $88 \%$ and $73 \%$, respectively. It is noteworthy to point that treatment times varied between 12.1 to $22.3 \mathrm{~min}$, according to the applicator diameter [11]. Ongoing prospective trials (NCT03226483, NCT04690348) and the initiation of an international $\mathrm{kV}$-IORT registry will deliver data on the future value of these technologies in the treatment of brain metastases.

\section{Abbreviations}

BM: Brain metastases; IORT: Intraoperative radiotherapy; IOERT: Intraoperative electron radiotherapy; RN: Radionecrosis; kV: Kilovoltage; OAR: Organs at risk; WBRT: Whole-brain radiotherapy.

\section{Authors' contributions}

GRS: Data gathering, manuscript drafting, editing and formatting. CPC: Conceptualization, manuscript revision and editing. HK: Manuscript revision and editing. FAG: Conceptualization, manuscript revision, editing and correction. All authors read and approved the final manuscript.

\section{Funding}

No funding was received for this work.

Availability of data and materials Not applicable.

\section{Declarations}

Ethics approval and consent to participate

Not applicable.

\section{Consent for publication \\ Not applicable.}

\section{Competing interests}

G.R.S.: Personal fees from Carl Zeiss Meditec AG and Roche Pharma AG, not related to this work. C.P.C.: Hororaria for educational lectures from Carl Zeiss Meditec AG, not related to this work. H.K.: Personal fees from Carl Zeiss Meditec $A G$ and ELEKTA, not related to this work. F.A.G.: research grants and travel expenses from ELEKTA AB; grants, stocks, travel expenses and honoraria from NOXXON Pharma AG; research grants, travel expenses and honoraria from Carl Zeiss Meditec AG; travel expenses and honoraria from Bristol-Myers Squibb, Roche Pharma AG, MSD Sharp and Dohme GmbH and AstraZeneca GmbH; non-financial support from Oncare $\mathrm{GmbH}$ and Opasca $\mathrm{GmbH}$, not related to this work.

\section{Author details}

${ }^{1}$ Department of Radiation Oncology, University Hospital Bonn, University of Bonn, Venusberg Campus 1 Building 55, 53127 Bonn, Germany. ${ }^{2}$ Department of Neurosurgery and Radiation Oncology, West Virginia University, Morgantown, WV, USA. ${ }^{3}$ Department of Radiation Oncology, University Hospital Augsburg, Augsburg, Germany.

Received: 14 June 2021 Accepted: 4 July 2021

Published online: 10 July 2021

\section{References}

1. Minniti G, Niyazi M, Andratschke N, Guckenberger M, Palmer JD, Shih HA, Lo Simon S, Soltys S, Russo I, Brown PD et al. Current status and recent advances in resection cavity irradiation of brain metastases. Radiation Oncol. 2021;16(1):73

2. Zamorano L, Yakar D, Dujovny M, Sheehan M, Kim J. Permanent iodine-125 implant and external beam radiation therapy for the treatment of malignant brain tumors. Stereotact Funct Neurosurg. 1992;59(1-4):183-92.

3. Wernicke AG, Hirschfeld CB, Smith AW, Taube S, Yondorf MZ, Parashar B, Nedialkova L, Kulidzhanov F, Trichter S, Sabbas A, et al. Clinical outcomes of large brain metastases treated with neurosurgical resection and intraoperative cesium-131 brachytherapy: results of a prospective trial. Int J Radiat Oncol Biol Phys. 2017;98(5):1059-68.

4. Julie DA, Lazow SP, Vanderbilt DB, Taube S, Yondorf MZ, Sabbas A, Pannullo S, Schwartz TH, Wernicke AG. A matched-pair analysis of clinical outcomes after intracavitary cesium-131 brachytherapy versus stereotactic radiosurgery for resected brain metastases. J Neurosurg;2020:1-8.

5. Chitti B, Goyal S, Sherman JH, Caputy A, Sarfaraz M, Cifter G, Aghdam H, Rao YJ. The role of brachytherapy in the management of brain metastases: a systematic review. J Contemp Brachytherapy. 2020;12(1):67-83.

6. Beck C. Über Kombinationsbehandlung bei bösartigen Neubildungen. Berliner klinische Wochenschrift. 1907;44:1355-438.

7. Sethi A, Emami B, Small W, Thomas TO. Intraoperative radiotherapy with INTRABEAM: technical and dosimetric considerations. Front Oncol. 2018;8(74).

8. Brown PD, Ballman KV, Cerhan JH, Anderson SK, Carrero XW, Whitton AC, Greenspoon J, Parney IF, Laack NNI, Ashman JB et al. Postoperative stereotactic radiosurgery compared with whole brain radiotherapy for resected metastatic brain disease (NCCTG N107C/CEC.3): a multicentre, randomised, controlled, phase 3 trial. Lancet Oncol. 2017;18(8):1049-60.

9. Nakamura O, Matsutani M, Shitara N, Okamoto K, Kaneko M, Nakamura H, Asai A, Ueki K, Shimizu T, Tanaka Y, et al. New treatment protocol by intraoperative radiation therapy for metastatic brain tumours. Acta Neurochir (Wien). 1994;131(1-2):91-6.

10. Vargo JA, Sparks KM, Singh R, Jacobson GM, Hack JD, Cifarelli CP. Feasibility of dose escalation using intraoperative radiotherapy following 
resection of large brain metastases compared to post-operative stereotactic radiosurgery. J Neurooncol. 2018;140(2):413-20.

11. Cifarelli CP, Brehmer S, Vargo JA, Hack JD, Kahl KH, Sarria-Vargas G,

Giordano FA. Intraoperative radiotherapy (IORT) for surgically resected brain metastases: outcome analysis of an international cooperative study. J Neuro Oncol. 2019;145(2):391.

\section{Publisher's Note}

Springer Nature remains neutral with regard to jurisdictional claims in published maps and institutional affiliations.
Ready to submit your research? Choose BMC and benefit from:

- fast, convenient online submission

- thorough peer review by experienced researchers in your field

- rapid publication on acceptance

- support for research data, including large and complex data types

- gold Open Access which fosters wider collaboration and increased citations

- maximum visibility for your research: over $100 \mathrm{M}$ website views per year

At BMC, research is always in progress.

Learn more biomedcentral.com/submissions 